NBER WORKING PAPER SERIES

\title{
WHEN ARE GHETTOS BAD? LESSONS FROM IMMIGRANT SEGREGATION IN THE UNITED STATES
}

\author{
David M. Cutler \\ Edward L. Glaeser \\ Jacob L. Vigdor \\ Working Paper 13082 \\ http://www.nber.org/papers/w13082 \\ NATIONAL BUREAU OF ECONOMIC RESEARCH \\ 1050 Massachusetts Avenue \\ Cambridge, MA 02138 \\ May 2007
}

We are grateful to the Russell Sage Foundation for support and to Audrey Beck for outstanding research assistance. We also thank participants in the 2005 American Real Estate and Urban Economics Association International Conferences for helpful comments on a previous draft. This paper reports the results of research and analysis undertaken while the corresponding author was a research affiliate at the Center for Economic Studies at the U.S. Census Bureau. It has undergone a Census Bureau review more limited in scope than that given to official Census Bureau publications. Research results and conclusions expressed are those of the authors and do not necessarily indicate concurrence by the Census Bureau. It has been screened to insure that no confidential information is revealed. The segregation indices used in this paper are available on our website: http://trinity.aas.duke.edu/ jvigdor/segregation. The views expressed herein are those of the author(s) and do not necessarily reflect the views of the National Bureau of Economic Research.

(C) 2007 by David M. Cutler, Edward L. Glaeser, and Jacob L. Vigdor. All rights reserved. Short sections of text, not to exceed two paragraphs, may be quoted without explicit permission provided that full credit, including (C) notice, is given to the source. 
When Are Ghettos Bad? Lessons from Immigrant Segregation in the United States David M. Cutler, Edward L. Glaeser, and Jacob L. Vigdor

NBER Working Paper No. 13082

May 2007

JEL No. J15,R2

\begin{abstract}
Recent literature on the relationship between ethnic or racial segregation and outcomes has failed to produce a consensus view of the role of ghettos; some studies suggest that residence in an enclave is beneficial, some reach the opposite conclusion, and still others imply that any relationship is small. This paper presents new evidence on this relationship using data on first-generation immigrants in the United States. Using average group characteristics as instruments for segregation, controlling for individual characteristics and both metropolitan area and country-of-origin fixed effects, we estimate impacts of residential concentration that vary with group human capital levels. Residential concentration can be beneficial, but primarily for more educated groups. The mean impact of residential concentration varies across measures, which may illuminate some of the causal mechanisms relating segregation to outcomes.

David M. Cutler

Department of Economics

Harvard University

1875 Cambridge Street

Cambridge, MA 02138

and NBER

dcutler@harvard.edu

Edward L. Glaeser

Department of Economics

315A Littauer Center

Harvard University

Cambridge, MA 02138

and NBER

eglaeser@harvard.edu

Jacob L. Vigdor

Terry Sanford Institute of Public Policy

Duke University

Durham, NC 27708

and NBER

jacob.vigdor@duke.edu
\end{abstract}




\section{Introduction}

Over the past decade, social scientists have devoted a considerable amount of effort to identifying the effect of neighborhood-level factors on individual outcomes. In response to the traditional concern regarding families' endogenous choice of neighborhoods, researchers have adopted an array of techniques, including simple bounds analyses (Solon, Page and Duncan 2000; Page and Solon 2003), propensity score matching methods (Harding 2003), instrumental variables (Cutler and Glaeser 1997), quasi- or “natural” experiments (Aaronson 1998;

Oreopoulos 2003; Jacob 2004), and actual randomized controlled trials (Kling and Liebman 2004; see Vigdor 2006 for a review of recent literature on neighborhood effects). From a scientific perspective, it would be comforting to find a consensus on the direction and magnitude of neighborhood effects. No such consensus exists. A review of the recent literature finds considerable heterogeneity in conclusions. While a careful reader could certainly find flaws in even the most carefully conducted studies to date, a reasonable implication to take from existing literature is that neighborhood effects are not monolithic in nature: the relationship between neighborhood characteristics and individual outcomes depends on characteristics both of the context and of the individual.

Among the most prominent neighborhood characteristics examined in existing literature is racial or ethnic concentration, often as proxied by a segregation index. Cutler and Glaeser (1997) find significant negative relationships between segregation and outcomes for AfricanAmericans in 1990. Subsequent research on segregation and outcomes has found either no association or a reversed relationship, using earlier data on African-Americans (Collins and Margo 2000) or quasi-experimental evidence on immigrants in Sweden (Edin, Fredriksson and 
Aslund, 2003). A fair reading of existing evidence, then, suggests that ghettos may be either good or bad for outcomes.

What determines whether segregation has a positive or negative impact on outcomes? This paper seeks insight into this question by examining the experiences of immigrant groups in the United States, utilizing newly computed segregation indices for immigrants of roughly 100 different nationalities living in any of roughly 300 metropolitan statistical areas (MSAs). To address the important concern that immigrants sort themselves into enclaves nonrandomly, we employ two basic strategies. The first involves the use of both country-of-origin and MSA fixed effects. In these specifications, we identify the impact of segregation by comparing groups that are more and less segregated within a city, relative to their own group-level averages. Second, we conduct an instrumental variables analysis. Our instrument for segregation is the mean number of years since immigration for group members in a particular MSA. More recently arrived groups tend to be less segregated. We control directly for an individual's years since immigration, which should directly capture any assimilation effects. We also control for average group age and education level in the second stage regression. ${ }^{1}$

Existing literature can be divided into papers directly examining the effects of ethnic concentration in one's neighborhood, and to those that concentrate on the effect of average concentration in one's MSA. In this paper, we perform both types of analysis. To conduct the second analysis, we make use of restricted-access Census microdata, employing control strategies similar to those used in the first analysis. Our instrument for neighborhood concentration is an imputed variable, equal to the concentration level predicted on the basis of

1 As discussed below, if we violate the exclusion restriction in spite of these efforts, the expected impact is to bias the results of the IV regressions towards OLS. Results will reveal significant differences between OLS and IV specifications. 
the distribution of individuals by occupation across tracts in an MSA, and for the observed national occupation distribution of the group in question.

Our results point towards a relationship between segregation and outcomes that corroborates some earlier findings: segregation tends to have more beneficial effects for groups with higher levels of average human capital (Edin, Fredriksson and Aslund, 2003; Cutler, Glaeser and Vigdor 2005a). We also find notable differences between the estimated impact of segregation and the impact of neighborhood concentration. In many cases, the average effect of segregation on outcomes is positive, while the effect of neighborhood concentration is negative. Together, the results imply that residence near, but not in, an enclave can be beneficial to a certain class of immigrant, perhaps professionals or entrepreneurs who serve the community.

While our motivation to study immigrant ghettos in the United States clearly relates to a desire to understand the mechanisms underlying ethnic and racial concentration effects more generally, we should also note that there is a compelling specific reason to study this population at this time. As Figure 1 indicates, immigrant segregation has been rising in the United States since the mid-twentieth century. Cutler, Glaeser and Vigdor (2005b) show that only a small portion of this increase can be attributed to changing characteristics of immigrants themselves; a larger portion relates to the changing form of American cities and the tendency for immigrants to participate less fully in the process of suburban sprawl. Rising segregation need not be a public policy concern if segregation has few or no negative consequences. Results presented here suggest that at least in some cases, such a sanguine view is not warranted.

Section 2 discusses the potential benefits and costs of ethnic concentration. Section 3 reviews our sources of data and methods. Section 4 presents results, and section 5 concludes. 


\section{How might ghettos impact immigrants?}

Arguments and theoretical models considering the potential impacts of segregation can be found in the existing literature (Cutler and Glaeser, 1997; Borjas, 1998; Edin, Fredriksson and Aslund, 2003). In this section, we briefly review the hypothesized benefits and costs of enclave residence.

\subsection{The benefits of segregation}

Residence in an enclave community might have beneficial impacts on immigrant's income and consumption possibilities. Ethnic density may foster the formation of group-specific networks that provide access to employment opportunities and transportation. Residential concentration may also be necessary for groups to form a critical mass necessary to support group-specific commercial enterprises or community institutions (Waldfogel, 2003). Generally

speaking, the benefits associated with segregation can be thought of as reducing the costs of assimilation to the host society, primarily by making that process less necessary to economic success.

\subsection{The costs of segregation}

While many of the benefits associated with residence in an enclave are immediate in nature, many of the hypothesized costs accrue over a longer period of time. Enclave communities are often located in older residential areas, further from suburban areas of job growth in most MSAs. Thus, while the availability of employment and transportation networks may assist immigrants in the short run, the relative difficulty of expanding beyond these 
networks could cause harm in the long run. This hypothesized impact relates to the spatial mismatch hypothesis (Kain 1968), long discussed as a possible mechanism linking racial segregation to poor labor market outcomes for African-Americans.

Because of their tendency to be located in older neighborhoods, ethnic enclaves are disproportionately likely to be served by relatively strained central city or inner-ring suburb governments. Lower quality of local public goods, particularly primary and secondary education, may have a strong negative impact on family welfare, albeit one only observed with a significant time lag. Other local disamenities, such as crime, may impact immigrants more immediately. Cutler, Glaser and Vigdor (2005b) show evidence that the availability of one locally-provided public good, transit, may play a disproportionate role in immigrant location decisions. To the extent that investments in transit crowd out other categories of public expenditure, enclave residents may suffer in the long run.

Beyond these costs associated with physical location of the ghetto, isolated immigrants may more generally exhibit reduced rates of economic and cultural assimilation. Exposed disproportionately to people like themselves, group members may retain group characteristics for a longer period of time. For less-educated or lower-skilled immigrant groups, this implies lower future income for present and future generations. For higher-skilled groups, of course, isolation from the less-skilled majority may actually be beneficial. The impact of segregation on human capital accumulation quite possibly depends on the characteristics of the segregated group (Borjas 1998; Edin, Fredriksson and Aslund 2003; Cutler, Glaeser and Vigdor 2005a).

Given the presence of short-term benefits and longer-term costs, an immigrant's optimal strategy may be to locate in an enclave community initially, then move out once a certain amount 
of assimilation has taken place. Indeed, empirical evidence supports the notion that immigrants tend to reduce their degree of isolation as they spend more time in the host country (Cutler, Glaeser and Vigdor 2005b, see also the first-stage regressions in Appendix Table A1). The selection of more-assimilated immigrants out of enclave communities poses a direct challenge to any efforts to estimate the relationship between segregation and outcomes. Immigrants living in isolated settings possess observable characteristics associated with more negative socioeconomic outcomes, it is reasonable to presume that these immigrants possess unfavorable unobserved characteristics as well. In general, then, we expect simple estimates of the relationship between segregation and outcomes to be biased downwards. Our strategies for circumventing this bias are detailed in the following section.

\section{Data and Methods}

\subsection{Basic information}

Our study of immigrant segregation and outcomes makes use of information collected in the US Decennial Census enumeration of $1990 .^{2}$ The Census contains information on country of birth for all foreign-born residents; we use this information to categorize immigrants by country of origin. ${ }^{3}$ Socioeconomic outcome measures derived from the Census include the logarithm of earned income in 1989, indicators for whether an individual was either gainfully employed or enrolled in school in the week prior to the enumeration, and whether a female was a single

2 We use 1990 data here primarily for purposes of comparability with Cutler and Glaeser (1997). Analyses completed with 2000 Census data, available from the authors on request, show similar patterns to those presented here.

3 The Census does not collect information on citizenship for foreign-born residents. There is some concern that the Census severely undercounts immigrants, particularly undocumented or "illegal" immigrants. We imagine that undocumented immigrants have relatively poor socioeconomic outcomes and have a disproportionate tendency to locate in immigrant enclaves. Thus, excluding these individuals from our sample should have the impact of reducing any estimated negative relationship between locations and outcomes. We hesitate to refer to our coefficients as biased, however, since much of the change in coefficients associated with including undocumented immigrants would doubtlessly represent selection bias rather than any true treatment effect. 
mother. These outcome variables mirror those used in Cutler and Glaeser (1997). As in that earlier paper, we restrict our attention to individuals between 20 and 30 years of age at the time of the enumeration, under the hypothesis that this group is more likely to have their residential location assigned by parental choice, rather than their own individual choice. This is not our only effort to address possible selection biases; our other efforts are described in more detail below.

In addition to these outcome measures, we examine three variables pertaining to younger immigrants. For children between the ages of 9 and 18, we analyze the probability of both speaking and writing English well. For children between 16 and 18 years of age, we consider the decision to enroll in school. Finally, for females 13 to 19 years old, we analyze the propensity to be a teenage mother. Summary statistics for these outcome variables and for the individual-level covariates controlled for in our analysis appear in Table 1.

\subsection{Measuring segregation and ethnic concentration}

There are many ways to measure segregation and ethnic concentration, and social scientists continue to find new, and arguably superior, ways to quantify both constructs (Massey and Denton 1988; Echenique and Fryer 2005). Our analysis makes use of two segregation indices, both of which are described in detail in Cutler, Glaeser and Vigdor (1999). The dissimilarity index, $D$, is defined as:

(1) $\quad$ D $=\frac{1}{2} \sum_{i} \mid \frac{\text { group }_{i}}{\text { group }_{\text {total }}}-$ non $-\frac{\text { group }_{i}}{\text { non }}-$ group $_{\text {total }} \mid$

where group $_{i}$ denotes the number of relevant immigrant group members living in neighborhood $i$, group $_{\text {total }}$ the number living in the entire city or metropolitan area, and non-group $i$ and non- 
group $_{\text {total }}$ are similarly defined for residents not belonging to the group in question. Dissimilarity equals zero in situations where a group forms an equal share of the population in all neighborhoods, and equals one when a group resides exclusively in neighborhoods where no non-group members live. Between these extremes, the dissimilarity index can be interpreted as the share of group members (or non-group members) that would have to switch neighborhoods in order to achieve an even distribution across the MSA.

While it possesses an intuitive interpretation, the dissimilarity index can easily be criticized (see, for example, Echenique and Fryer 2005). Among other criticisms, the dissimilarity index can record a group as being highly segregated even in situations where group members have extensive neighborhood-level exposure to non-group members. A group located exclusively in one neighborhood that only forms $10 \%$ of the population in that neighborhood, for example, would have a dissimilarity value close to one in a large MSA. While many alternative indices have been proposed that lack this undesirable property, our past work (Cutler, Glaeser and Vigdor 1999) focuses on one in particular, the isolation index. Isolation is defined as follows:

(2) $I=\frac{\sum_{i} \frac{\text { group }_{i}}{\text { group }_{\text {total }}} \times \frac{\text { group }_{i}}{\text { population }_{i}}-\frac{\text { group }_{\text {total }}}{\text { population }_{\text {total }}}}{\min \left(1, \frac{\text { group }_{\text {total }}}{\text { population }_{\text {smallest }}}\right)-\frac{\text { group }_{\text {total }}}{\text { population }_{\text {total }}}}$ where group $_{i}$ and group $_{\text {total }}$ are defined as above, population $_{i}$ and population $_{\text {total }}$ represent the overall population in tract $i$ and the entire city or metropolitan area, and population smallest $_{\text {is }}$ the population of the neighborhood with the fewest residents in the city or metropolitan area. At the extremes, isolation and dissimilarity take on the same values, zero and one. At intermediate 
values, isolation measures the extent to which the neighborhood-level group share experienced by the average group member exceeds the level that would be expected under perfect integration.

Either segregation index requires us to operationalize the concept of neighborhood. We compute segregation using Census tracts, which average 4,000 residents each though population size varies. Arguments can be made for using either larger or smaller geographic areas as the unit of analysis; tracts have the advantage that they are defined consistently throughout the country and have a rich array of demographic data available for analysis in public use summary files.

Figure 1 displays the time pattern of immigrant segregation since 1910, using the two indices defined above. The plotted values are averages of immigrant group/city specific observations, weighted by the number of group members in the city in the indicated year. Both dissimilarity and isolation have been rising over the past several decades, though the 1990s witnessed relative stability in dissimilarity levels. Cutler, Glaeser and Vigdor (2005b) analyze the time series and cross-sectional variation in immigrant segregation over this time period. Summary statistics for immigrant segregation indices used in the analysis below appear in Table 1.

Segregation indices can be considered a measure of the average degree of neighborhood concentration experienced by a group member in a particular MSA. The use of this proxy measure instead of actual neighborhood-level exposure can be justified on two grounds, one pratical and the other statistical. First, there are very few datasets that provide microdata on individual outcomes coupled with neighborhood-level geographic identifiers. Segregation indices serve as an imperfect proxy measure for this neighborhood-level information, capturing 
the actual neighborhood concentration of each resident with some degree of error. If these measurement errors are uncorrelated with individual characteristics, no bias should be introduced into the analysis.

Of course, the decision to locate in a segregated or integrated environment within a metropolitan area is almost certainly related to a host of individual characteristics. This simple fact provides the second rationale for using MSA-level segregation indices as a proxy for neighborhood-level concentration: endogeneity problems are likely to be more severe when using finer geographic detail. It is easier to argue that individuals choose an MSA without regard to the degree of segregation than to say that they choose a neighborhood without regard to racial or ethnic composition.

In section 4.2 below, we present an analysis of the relationship between neighborhoodlevel ethnic exposure and socioeconomic outcomes for immigrants. This analysis makes use of restricted-access Census microdata, which combine the same set of individual demographic and socioeconomic information available in public use microdata samples with finer geographic identification. The following section describes our efforts to address selection bias in this analysis and the more general study of immigrant segregation and outcomes.

\subsection{Addressing selection bias}

Estimates of the impact of ethnic concentration on socioeconomic outcomes will be biased to the extent that individuals with unobservably inferior (or superior) characteristics sort into more (or less) concentrated neighborhoods, or to MSAs with higher (or lower) average levels of neighborhood concentration. Previous literature has sought to address this bias in a 
number of ways, including the analysis of actual randomized neighborhood assignment trials and the use of quasi- or natural experiments. The estimates we present below adopt a series of strategies to infer the impact of selection bias on the results.

First, we present results that incorporate both MSA and country-of-origin fixed effects. With these fixed effects in place, our effects of interest are identified from variation in the extent of segregation for immigrant groups residing in the same city, except for that variation that stems from differences in the average segregation level across groups. These fixed effects eliminate many potential sources of bias. For example, one common concern is that segregation tends to be higher in older MSAs with a heavier reliance on manufacturing industry, public transit, and the like. These characteristics may in turn predict worse (or better) outcomes for immigrants. Fixed effects eliminate this concern. A second example would be a concern that a particularly uneducated immigrant group shows a tendency to form residential enclaves wherever they locate, and its members experience poor outcomes regardless of the actual segregation level. This concern is also addressed with the fixed effects strategy.

The fixed-effects strategy is certainly not flawless. If immigrants with unobserved skill levels lower than their group-level average tend to sort into ethnically concentrated environments, wherever they may be, then selection bias will still influence our estimates. Thus, while we believe the fixed effects strategy addresses many selection concerns, it does not address all of them. Evidence that estimates with and without fixed effects are substantially similar would bolster our confidence that selection bias is a relatively minor concern.

To further address selection bias issues, we employ instrumental variable (IV) strategies in specifications examining both MSA-level segregation and tract-level ethnic concentration. A 
successful IV research design involves one or more variables that influence segregation but have no other statistical relationship, causal or otherwise, with the dependent variable. In specifications examining segregation indices, we instrument for segregation with a measure of the mean years since immigration for members of a country-of-origin group within a city. There are two primary concerns regarding the exclusion restriction for these models. First, years since immigration can be considered a measure of assimilation, which could directly impact outcomes. To address this, we control separately in the regression for an individual immigrant's own years since immigration. A second concern is that employers or other agents may statistically discriminate against members of a group on the basis of average group characteristics, including years since immigration. To address this concern, we control directly for two other city/group level characteristics that are arguably more likely to inspire statistical discrimination: average age and average education levels. Age is more directly observable than years since immigration, and education is a more reliable predictor of an individual's skill level. Representative first stage regression specifications are reported in Appendix Table A1. Immigrant groups tend to be significantly less segregated as they spend more time in the United States. ${ }^{4}$

In our tract-level ethnic concentration specifications, we instrument for concentration with a simulated measure that takes the total number of group members in an MSA, the distribution of non-group members, the nationwide distribution of occupations for each group, and the MSA-specific distribution of individuals by occupation across tracts as given. A predicted concentration level is computed for each group in each tract according to the following

4 One might still maintain that the group's average years since immigration correlates with some unobserved individual characteristic. The most likely scenario, arguably, is that immigrants belonging to groups with more years since immigration are unobservably more assimilated, and should hence have more positive economic outcomes. In this scenario, the IV results would reflect a bias toward the OLS results, as its central implication that residents of less segregated communities are unobservably predisposed to superior outcomes - is identical to the fundamental concern regarding OLS. 
formula:

(3) Predicted group size $=p_{i j} R_{i} O_{j}$

where Predicted group size is a $t$ by 1 vector of the simulated number of group members in tracts indexed $t, p_{i j}$ is a (scalar) measure of group $j$ 's population in MSA $i, R_{i}$ is a $t$ by $k$ matrix listing the share of persons with occupation $k$ residing within each of the $t$ tracts, and $O_{j}$ is a $k$ by 1 vector of the distribution of group $j$ members across the $k$ occupations. The predicted tract share is then computed by dividing predicted group size by the sum of predicted group size and the actual number of non-group members in the tract. Table A1 lists representative first stage regression specifications utilizing this instrument; in general it is a very strong predictor of actual group share. Immigrants tend to locate in neighborhoods that house individuals of similar skill levels.

\section{Results}

\subsection{The impact of segregation}

Tables $2 \mathrm{~A}$ and $2 \mathrm{~B}$ present sets of ordinary least squares regression results examining the relationship between segregation and outcomes for first-generation immigrants in the United States in 1990. Table 2A uses the dissimilarity index as a segregation measure, and table 2B focuses on the isolation index. Samples are restricted to individuals in the age ranges specified at the head of each column; males and females are included in all specifications except those for single and teen motherhood, which focus on females only.

Using either segregation index as the independent variable of interest, coefficients across specifications are generally small and equally likely to be of a sign associated with positive or 
negative impacts of segregation. The sole exception, in both tables, is the specification examining the logarithm of earned income in the previous year. Both dissimilarity and isolation have a statistically significant positive association with this outcome. The magnitude of the estimated effects is sizable; a one-standard deviation increase in dissimilarity, for example, predicts a $15 \%$ increase in earned income.

Coefficients on several other control variables merit at least some discussion here. Each specification in both tables controls separately for a group's share of the population, since that variable correlates with segregation and may have independent effects on outcomes (Cutler, Glaeser and Vigdor 2005b). In these specifications, group share correlates negatively with youth outcomes such as English language ability and school enrollment, with statistically significant coefficients in three out of four cases. Group share associates positively with earned income.

Immigrants who have spent more time in the United States, other things equal, experience superior labor market and schooling-related outcomes. This could reflect either the impact of assimilation or the tendency for immigrants with worse labor market outcomes to leave the country. Outcomes for childbearing-related outcomes do not follow this pattern, which may indicate age effects that are not properly reflected in our linear control, but might also indicate assimilation of another form: towards American-style rates of single and teen motherhood.

Other individual characteristics have generally predictable effects on these outcomes. Higher education levels are associated with better socioeconomic outcomes. Controlling categorically for year of entry, older immigrants (i.e. those who entered the US at a later age) have worse outcomes along a number of dimensions, with the exception of earnings - returns to age in the immigrant population appear to be quite strong. We estimate significant gaps in labor 
market outcomes for females and immigrants identifying themselves with a racial category other than white.

Average characteristics of an immigrant's fellow group members living in the same MSA show up as significant predictors of most outcomes. Immigrants belonging to older groups fare better on educational outcomes but worse in the labor market. Given that this analysis focuses on younger first-generation immigrants, higher average ages might represent a higher proportion of these individuals' parents residing in the same MSA. Parents might encourage their children to receive more education. Parent-generation immigrants, who presumably are less likely to be employed in entry-level jobs, may be less beneficial when it comes to providing employment connections.

Immigrants belonging to more educated groups fare better on all outcomes. These effects may represent true "ethnic capital" type mechanisms (Borjas, 1995), or might simply reflect a correlation between unobserved individual characteristics and group average characteristics.

Aside from incorporating a few individual- and group-level covariates, the specifications in Table 2A and 2B do very little to address concerns of endogenous immigrant sorting into enclave environments. Tables $3 \mathrm{~A}$ and $3 \mathrm{~B}$ take a further step in this regard, presenting coefficients from specifications that incorporate MSA and country-of-origin specific fixed effects. As in the previous two tables, there are generally few significant links between segregation, as measured by either dissimilarity or isolation, and the set of outcomes under consideration. Of the three coefficients appearing significantly, two imply that segregation has beneficial effects: dissimilarity predicts lower levels of idleness, and isolation predicts greater English proficiency. 
Perhaps most notably, the one significant association found in the earlier tables, between segregation and earned income, is no longer present in these specifications. The apparent tendency for immigrants to earn more when more segregated can be explained by patterns of higher earnings in generally more segregated cities, or by a tendency for immigrant groups prone to segregation to earn more. Within cities and within groups, estimated effects are reduced substantially in the case of isolation, and appear with an opposite sign (and marginal statistical significance) in the case of dissimilarity. This pattern indicates the existence of a positive bias in OLS estimates: immigrants with more favorable unobserved characteristics belong to groups that tend to be universally more segregated, or reside in cities where immigrant segregation tends to be higher.

The addition of MSA and country-of-origin fixed effects also reduces the magnitude and significance of virtually every coefficient on group average characteristics. Of the 24 group average characteristics coefficients appearing in Tables 2A and 2B, 20 attained some degree of statistical significance at conventional levels. Comparing Tables 3A and 3B, 23 of these 24 coefficients have either moved towards zero or reversed signs. Of the six coefficients that retain significance after the addition of fixed effects, four have the opposite sign relative to the original coefficient in Table 2A or 2B. The general effect of group-level education on outcomes continues to be positive in most cases. Group-level mean age now appears to have a modest, yet statistically significant, negative impact on English-speaking ability and an adverse impact on teen motherhood. For the most part, though, across-group differences in average characteristics appear to associate much more strongly with individual outcomes than within-group, across-city differences in average characteristics. This increases our confidence that our instrumental 
variable strategy, which exploits the strong association between a group-level characteristic and segregation levels, satisfies the exclusion restriction - that the group-level characteristic has no other association with the outcomes in question.

Instrumental variable estimates of the mean impact of segregation on outcomes appear in Tables 4A and 4B. These specifications continue to control for MSA and country-of-origin fixed effects, as in Tables 3A and 3B. Coefficients from representative first-stage regression specifications can be found in Appendix Table A1. While the selection concerns enunciated in section 3.3 above tended to presume a pattern of negative selection into enclave environments, the preceding results indicate that the bias may work in the other direction as well: segregated immigrant communities may attract either disproportionately skilled or unskilled immigrants.

Comparing results in Tables $4 \mathrm{~A}$ and $4 \mathrm{~B}$ with their OLS counterparts in Tables $3 \mathrm{~A}$ and $3 \mathrm{~B}$ reveals that IV coefficients are more positive (or closer to positive) in eleven of twelve cases. This pattern is a bit less conclusive than it might at first appear, as three of the dependent variables are scaled in such a way that positive values are associated with negative outcomes being a teen or single mother, or being idle. From this perspective, it is unclear what type of selection into segregated communities predominates. It should also be noted, however, that in four of the five cases where coefficient differences point toward positive selection, both OLS and IV coefficients are statistically indistinguishable from zero. On net, the stronger evidence supports the selection of less-skilled individuals into enclave communities.

The four significant coefficients on segregation indices in tables $4 \mathrm{~A}$ and $4 \mathrm{~B}$ are found in specifications examining two dependent variables: the English ability of young first-generation immigrants and the logarithm of earnings for young adults. Both of these dependent variables 
had shown at least some evidence of a relationship with segregation in prior specifications. The magnitudes associated with these coefficients are generally reasonable: a one-standard deviation increase in isolation predicts a 1.7 percentage point increase in the probability of speaking and writing English, and a 5.4\% increase in earned income. Overall, the IV results suggest that immigrant ghettos are beneficial, improving the economic outcomes of immigrants while actually accelerating the assimilation of immigrant children. Residential concentration may improve language acquisition for foreign-born children by fostering the development of specialized curricular programs in local public schools. Two important questions remain, however. Are ghettos equally benign for all immigrant groups? Does the analysis of segregation and outcomes really give us an accurate portrait of the true impact of living in a concentrated ethnic enclave? The remainder of this section addresses these two questions.

\subsection{The impact of neighborhood-level group share}

The primary practical obstacle to the direct analysis of the effects of neighborhood ethnic concentration on socioeconomic outcomes is the lack of microdata with sufficient geographic detail to link individuals to neighborhoods. This obstacle can be surmounted with restrictedaccess Census microdata made available by the Census Bureau through its Regional Data Center program. Table 5 presents an analysis using these data, relating the neighborhood-level ethnic concentration experienced by foreign-born residents of the United States to a series of educational and labor market outcomes. ${ }^{5}$ These specifications employ both metropolitan area and country-of-origin fixed effects, and are thus most comparable to the segregation index-based

5 Fertility-related outcomes are not included in this analysis, primarily because our initial application to use the RDC restricted-access household dataset did not explicitly mention these outcomes. Census Bureau confidentiality rules also prohibit the disclosure of results utilizing cell sizes below a specific value. 
estimates presented in Tables $3 \mathrm{~A}$ and $3 \mathrm{~B}$.

In each reported specification, the share of a respondent's Census tract belonging to the same country-of-origin group appears as a significant predictor of labor market and educational outcomes. In three of four cases, the estimated effect is adverse. Young adult immigrants residing in more concentrated neighborhoods are more likely to be idle, and report lower earnings. Immigrant children residing in such neighborhoods are less likely to speak and read English proficiently, but more likely to be enrolled in school at ages 16 through 18 . Each of these results holds controlling for the same set of individual- and group-level covariates used in earlier specifications.

The strength of these results represents a marked contrast with the generally inconclusive patterns observed in Tables 3A and 3B. In only one instance does a significant tract share coefficient in Table 5 coincide with a significant segregation index coefficient in the earlier tables: dissimilarity was estimated to have a moderately significant negative impact on earnings in Table 3A. This lack of concordance sounds a cautionary note for studies employing segregation indices as explanatory variables in studies of socioeconomic outcomes: while these indices serve as summary statistics for neighborhood-level indicators, they generally do a poor job of replicating the results obtained with true neighborhood-level data.

There are serious threats to causal interpretation of the coefficient estimates in Table 5. While these regressions control for a number of individual characteristics, as well as MSA and group fixed effects, individual sorting on unobservables into neighborhoods with varying ethnic concentration could still produce inconsistency here. In Table 6, we provide instrumental variable estimates that essentially exploit the tendency for American metropolitan areas to be 
economically segregated, and for immigrant groups to form an unrepresentative socioeconomic sample of the broader population.

Instrumental variable estimates continue to show strong, statistically significant associations between tract share and the English ability of child immigrants, and between tract share and the earnings of young adult immigrants. A ten percentage point increase in share predicts a 1 percentage point decrease in the probability of English fluency, and a $2.7 \%$ reduction in earnings. In the other two specifications, the statistical significance realized in OLS estimates is eliminated. Comparison of OLS and IV estimates provides no uniform signal regarding the direction of bias in OLS. Effects appear less favorable in three out of four specifications, with the exception being idleness: a significant association in OLS is replaced with an insignificant relationship in the IV model. The preponderance of evidence suggests that individuals predisposed towards positive outcomes choose to reside in enclave neighborhoods.

\subsection{Heterogeneity of effects}

Not all ghettos have the same impact on their residents: this is the simple logical conclusion of existing research on the subject, which has found a combination of positive, negative, and null impacts. Following previous work on the subject, the regression specifications in Table 7 test for a simple form of heterogeneity in the effect of dissimilarity and isolation on outcomes. In this table, dependent variables appear in rows and each pair of columns represents a different regression specification. The table reports OLS-fixed effect results and IV results pertaining to both the Dissimilarity and Isolation indices. The first coefficient reported in each pair is the main effect of segregation, the second is the coefficient on the interaction of segregation with the average education level variable included as a covariate in earlier analyses. 
The main effect can thus be interpreted as the impact of segregation on an immigrant group where the mean level of education is zero. The interaction term identifies the change in the marginal impact of segregation associated with a one-year increase in average education levels. In IV specifications, both the main effect and interaction term are instrumented for, with the mean years-since-immigration variable and its interaction with mean education.

The OLS specifications in this case reveal very few significant patterns. The two sets of results that do appear link the most positive impacts of segregation to the lowest-education groups. These effects are significant only at the $10 \%$ level, and both are directly contradicted by evidence available in the corresponding IV specification.

In instrumental variables specifications, a fairly consistent result pattern emerges in the analysis of three dependent variables: English ability, single motherhood, and the logarithm of earned income. Segregation, whether measured by dissimilarity or isolation, predicts worse outcomes for groups with the least education, and better outcomes for highly educated groups. Depending on the particular point estimates, the crossover from negative to positive segregation effects occurs at mean education levels between $10^{\text {th }}$ grade and minimal post-secondary education. Thus, isolation in an enclave where most adults have post-secondary degrees appears beneficial in many respects, while isolation in an enclave where most adults have education below minimum domestic standards appears harmful.

Table 8 presents results of analogous specifications that interact tract-level group share variables with group mean education levels, utilizing restricted-access Census microdata. Coefficients derived from OLS specifications with MSA and country-of-origin fixed effects, like their Table 7 counterparts, are generally inconclusive. Interaction terms are insignificant in three 
of four specifications, and main effects suggest widely varying impacts of ethnic concentration on outcomes for low-skilled immigrant groups. As in the previous table, IV estimates present a more consistent picture. In three of four specifications, neighborhood-level ethnic concentration displays a statistically significant moderated relationship with individual outcomes, with more negative effects occurring among groups with lower average education levels. Among low skilled groups, ethnic concentration is associated with lower English fluency, lower earnings, and higher rates of idleness. These associations weaken as the skill level of the group increases. Around the population average of 10 years of education, implied effects are close to zero in all cases. These effects are generally consistent with the evidence derived from segregation indices presented in Table 7.

Overall, the results presented in this section indicate that the effects of ethnic concentration are dependent on the skill level of the group in question. Moreover, the use of segregation indices as a summary measure of ethnic concentration produces the most reliable results in specifications that permit this form of effect heterogeneity.

\section{Conclusions}

Ghettos are neither monolithically good nor bad. Existing literature points toward this conclusion, and the evidence presented in this paper supports it. The total impact of residence in an ethnic enclave depends on the characteristics of the individuals who are isolated in it. Groups with high average levels of human capital appear to benefit from segregation, while lesseducated communities suffer.

A second implication of this paper is that a study of the mean impact of segregation may provide a misleading estimate of the actual impact of residing in an enclave neighborhood. 
While many estimates point towards a positive average impact of segregation on outcomes for immigrant groups in the United States, equivalent estimates focusing on neighborhood-level ethnic concentration reach the opposite conclusion. Both estimates based on analysis of segregation and of actual neighborhood concentration support the conclusion that isolation is less harmful for more-skilled ethnic groups.

\section{References}

Aaronson, D. (1998) "Using Sibling Data to Estimate the Impact of Neighborhoods on Children's Educational Outcomes." Journal of Human Resources v.33 pp.915-946.

Borjas, G. (1998) "To Ghetto or Not to Ghetto: Ethnicity and Residential Segregation." Journal of Urban Economics, v.44 pp.228-253.

Collins, W.J. and R.A. Margo (2000) "Residential Segregation and Socioeconomic Outcomes: When Did Ghettos Go Bad?" Economics Letters v.69 pp.239-43.

Cutler, D.M. and E.L. Glaeser (1997) “Are Ghettos Good or Bad?” Quarterly Journal of Economics v.112 pp.827-872.

Cutler, D.M., E.L. Glaeser and J.L. Vigdor (2005a) "Ghettos and the Transmission of Ethnic Capital." in Ethnicity, Social Mobility, and Public Policy: Comparing the US and UK, G. Loury, T. Modood and S. Teles, eds. Cambridge: Cambridge University Press.

Cutler, D.M., E.L. Glaeser and J.L. Vigdor (2005b) "Is the Melting Pot Still Hot? Explaining the Resurgence of Immigrant Segregation.” NBER Working Paper \#11295.

Echenique, F. and R.G. Fryer (2005) "On the Measurement of Segregation." NBER Working Paper \#11258.

Edin,P., P. Fredriksson and O. Aslund (2003) "Ethnic Enclaves and the Economic Success of Immigrants: Evidence from a Natural Experiment." Quarterly Journal of Economics v.118 pp.329-357.

Harding, D.J. (2003) "Counterfactual Models of Neighborhood Effects: The Effect of Neighborhood Poverty on Dropping Out and Teenage Pregnancy." American Journal of Sociology v.109 pp.676-719. 
Jacob, B.A. (2004) "Public Housing, Housing Vouchers, and Student Achievement: Evidence from Public Housing Demolitions in Chicago." American Economic Review v.94 pp.

Kain, J.F. (1968) "Housing Segregation, Negro Employment, and Metropolitan Decentralization." Quarterly Journal of Economics v.82 pp.175-197.

Kling, J.R. ad J.B. Liebman (2004) "Experimental Analysis of Neighborhood Effects on Youth." Unpublished manuscript.

Massey, D.S. and N.A. Denton (1988) "The Dimensions of Residential Segregation." Social Forces v.67 pp.281-315.

Oreopoulos, P. (2003) "The Long-Run Consequences of Living in a Poor Neighborhood." Quarterly Journal of Economics v.118 pp.1533-1575.

Page, M.E. and G. Solon (2003) "Correlations between Brothers and Neighboring Boys in their Adult Earnings." Journal of Labor Economics v.21 pp.831-55.

Solon, G., M.E. Page and G.J. Duncan (2000) "Correlations between Neighboring Children in Their Subsequent Educational Attainment." Review of Economics and Statistics v.83 pp.383-92.

Vigdor, J.L. (2006) "Peer Effects in Neighborhoods and Housing." Forthcoming, Deviant Peer Influences in Programs for Youth: Problems and Solutions, K.A. Dodge, T.J. Dishion and J.E. Lansford, eds. New York: Guilford Press.

Waldfogel, J. (2003) "Preference Externalities: An Empirical Study of Who Benefits Whom in Differentiated-Product Markets." RAND Journal of Economics v.34 pp.557-68. 
Table 1: Outcome Regression Descriptive Statistics, IPUMS 1990

\begin{tabular}{|c|c|c|c|c|c|}
\hline Dependent Variables & $\mathrm{N}$ & Mean & SD & Min & Max \\
\hline English Ability & 14137 & 0.953 & - & - & - \\
\hline School Enrollment & 5637 & 0.791 & - & - & - \\
\hline Teen Mother & 5636 & 0.068 & - & - & - \\
\hline Single Mother & 14293 & 0.130 & - & - & - \\
\hline Wage Income (logged) & 22564 & 9.166 & 0.988 & 0.693 & 12.185 \\
\hline Idle & 30584 & 0.208 & - & - & - \\
\hline \multicolumn{6}{|l|}{ Covariates } \\
\hline Isolation & 4101 & 0.006 & 0.017 & 0 & 0.234 \\
\hline Dissimilarity & 4101 & 0.225 & 0.321 & 0 & 0.980 \\
\hline Immigrant Share & 4101 & 0.002 & 0.010 & 0 & 0.228 \\
\hline Mean Age & 4101 & 38.109 & 11.324 & 2 & 90 \\
\hline Mean Years in US & 4101 & 974.87 & 8.098 & 949 & 990 \\
\hline Mean Education & 4101 & 9.904 & 2.115 & 1 & 17 \\
\hline Entered 1987-1990 & 46831 & 0.239 & - & - & - \\
\hline $1985-1986$ & 46831 & 0.138 & - & - & - \\
\hline 1982-1984 & 46831 & 0.136 & - & - & - \\
\hline $1975-1981$ & 46831 & 0.316 & - & - & - \\
\hline $1960-1974$ & 46831 & 0.171 & - & - & 一 \\
\hline Education & 46831 & 8.367 & 3.458 & 1 & 17 \\
\hline Age & 46831 & 21.706 & 5.916 & 9 & 30 \\
\hline Female & 46831 & 0.471 & - & - & - \\
\hline Black & 46831 & 0.070 & - & - & - \\
\hline Other Non-White & 46831 & 0.754 & - & - & - \\
\hline
\end{tabular}


Table 2A: Dissimilarity and outcomes: OLS results

\begin{tabular}{|c|c|c|c|c|c|c|}
\hline Independent variable & $\begin{array}{l}\text { English Ability } \\
\quad \text { (age 9-18) }\end{array}$ & $\begin{array}{l}\text { Enrollment } \\
\text { (age 16-18) }\end{array}$ & $\begin{array}{l}\text { Single Mother } \\
\text { (age 20-30) }\end{array}$ & $\begin{array}{l}\text { Teen Mother } \\
\text { (age 13-19) }\end{array}$ & $\begin{array}{l}\ln (\text { Earnings }) \\
\text { (age } 20-30)\end{array}$ & $\begin{array}{c}\text { Idle } \\
\text { (age } 20-30)\end{array}$ \\
\hline \multirow[t]{2}{*}{ Dissimilarity index } & 0.001 & 0.106 & 0.048 & -0.062 & $0.521 * *$ & -0.034 \\
\hline & $(0.068)$ & $(0.191)$ & $(0.121)$ & $(0.061)$ & $(0.253)$ & $(0.085)$ \\
\hline \multirow[t]{2}{*}{ Group share of MSA population } & $-0.399 * * *$ & $-0.549 *$ & -0.137 & 0.013 & $1.314 * * *$ & -0.124 \\
\hline & $(0.077)$ & $(0.312)$ & $(0.231)$ & $(0.066)$ & $(0.267)$ & $(0.128)$ \\
\hline \multirow[t]{2}{*}{ Year of entry $1985-86$} & $0.167 * * *$ & $0.098 * * *$ & $0.017 * *$ & $0.028 *$ & $0.260 * * *$ & $-0.056^{* * *}$ \\
\hline & $(0.020)$ & $(0.012)$ & $(0.231)$ & $(0.016)$ & $(0.015)$ & $(0.005)$ \\
\hline \multirow[t]{2}{*}{ Year of entry $1982-84$} & $0.232 * * *$ & $0.227 * * *$ & $0.069 * * *$ & $0.074 * * *$ & $0.259 * * *$ & $-0.073 * * *$ \\
\hline & $(0.030)$ & $(0.025)$ & $(0.013)$ & $(0.018)$ & $(0.009)$ & $(0.005)$ \\
\hline \multirow[t]{2}{*}{ Year of entry $1975-81$} & $0.268 * * *$ & $0.256 * * *$ & $0.037 * * *$ & $0.061 * * *$ & $0.400 * * *$ & $-0.081 * * *$ \\
\hline & $(0.033)$ & $(0.012)$ & $(0.006)$ & $(0.015)$ & $(0.026)$ & $(0.006)$ \\
\hline \multirow[t]{2}{*}{ Year of entry $1960-74$} & $0.263 * * *$ & $0.259 * * *$ & $0.058 * * *$ & $0.067 * * *$ & $0.542 * * *$ & $-0.111 * * *$ \\
\hline & $(0.032)$ & $(0.024)$ & $(0.006)$ & $(0.010)$ & $(0.025)$ & $(0.008)$ \\
\hline Education & $0.044 * * *$ & $0.079 * * *$ & $-0.007 * *$ & $-0.022 * * *$ & $0.030 * * *$ & $-0.021 * * *$ \\
\hline \multirow[t]{2}{*}{ Age } & $-0.037 * * *$ & $-0.189 * * *$ & $0.003 * *$ & $0.055 * * *$ & $0.040 * * *$ & $0.004 * * *$ \\
\hline & $(0.002)$ & $(0.014)$ & $(0.002)$ & $(0.003)$ & $(0.007)$ & $(0.001)$ \\
\hline \multirow[t]{2}{*}{ Female } & $0.005 * *$ & -0.009 & - & - & $-0.418 * * *$ & $0.289 * * *$ \\
\hline & $(0.003)$ & $(0.006)$ & & & $(0.021)$ & $(0.021)$ \\
\hline \multirow[t]{2}{*}{ Black } & $0.056^{* * *}$ & $0.072 * *$ & $0.222 * * *$ & 0.053 & $-0.124 *$ & 0.057 \\
\hline & $(0.016)$ & $(0.035)$ & $(0.026)$ & $(0.033)$ & $(0.069)$ & $(0.045)$ \\
\hline \multirow[t]{2}{*}{ Other Non White } & $0.023 * *$ & $0.112 * * *$ & $0.067 * *$ & -0.001 & $-0.268 * * *$ & 0.008 \\
\hline & $(0.011)$ & $(0.034)$ & $(0.029)$ & $(0.019)$ & $(0.058)$ & $(0.032)$ \\
\hline \multirow[t]{2}{*}{ Average age of group members in MSA } & $0.005 * * *$ & $0.009 * * *$ & -0.0003 & $-0.002 * *$ & $-0.011 * * *$ & $0.003 * *$ \\
\hline & $(0.001)$ & $(0.002)$ & $(0.002)$ & $(0.001)$ & $(0.004)$ & $(0.001)$ \\
\hline \multirow{2}{*}{$\begin{array}{l}\text { Average education of group members in } \\
\text { MSA }\end{array}$} & $0.006 * *$ & $0.018^{*}$ & $-0.021 * * *$ & $-0.016^{* * *}$ & $0.061 * * *$ & $-0.019 * * *$ \\
\hline & $(0.003)$ & $(0.010)$ & $(0.008)$ & $(0.003)$ & $(0.016)$ & $(0.005)$ \\
\hline $\mathrm{R}^{2}$ & 0.2435 & 0.3584 & 0.0179 & 0.0963 & 0.1430 & 0.1445 \\
\hline
\end{tabular}

Note: Standard errors, in parentheses, have been adjusted to reflect within-immigrant-community clustering. Sample consists of foreign-born Census respondents.

*** denotes a coefficient significant at the $1 \%$ level, $* *$ the $5 \%$ level, * the $10 \%$ level. 
Table 2B: Isolation and outcomes: OLS results

\begin{tabular}{|c|c|c|c|c|c|c|}
\hline Independent variable & $\begin{array}{l}\text { English Ability } \\
\text { (age 9-18) }\end{array}$ & $\begin{array}{l}\text { Enrollment } \\
\text { (age 16-18) }\end{array}$ & $\begin{array}{l}\text { Single Mother } \\
\text { (age 20-30) }\end{array}$ & $\begin{array}{l}\text { Teen Mother } \\
\text { (age 13-19) }\end{array}$ & $\begin{array}{l}\ln (\text { Earnings }) \\
(\text { age } 20-30)\end{array}$ & $\begin{array}{c}\text { Idle } \\
\text { (age 20-30) }\end{array}$ \\
\hline \multirow[t]{2}{*}{ Isolation index } & -0.138 & -0.476 & -0.025 & 0.005 & $1.393 * *$ & -0.023 \\
\hline & $(0.147)$ & $(0.303)$ & $(0.291)$ & $(0.163)$ & $(0.551)$ & $(0.229)$ \\
\hline \multirow[t]{2}{*}{ Group share of MSA population } & $-0.322 * * *$ & -0.361 & -0.152 & 0.058 & 0.157 & -0.088 \\
\hline & $(0.108)$ & $(0.301)$ & $(0.311)$ & $(0.137)$ & $(0.417)$ & $(0.228)$ \\
\hline \multirow[t]{2}{*}{ Year of entry $1985-86$} & $0.167 * * *$ & $0.098 * * *$ & $0.017 * *$ & $0.028^{*}$ & $0.259 * * *$ & $-.056 * * *$ \\
\hline & $(0.020)$ & $(0.012)$ & $(0.007)$ & $(0.016)$ & $(0.015)$ & $(0.005)$ \\
\hline \multirow[t]{2}{*}{ Year of entry $1982-84$} & $0.232 * * *$ & $0.226 * * *$ & $0.069 * * *$ & $0.074 * * *$ & $0.259 * * *$ & $-0.073 * * *$ \\
\hline & $(0.033)$ & $(0.025)$ & $(0.013)$ & $(0.018)$ & $(0.009)$ & $(0.005)$ \\
\hline \multirow[t]{2}{*}{ Year of entry $1975-81$} & $0.268 * * *$ & $0.254 * * *$ & $0.038 * * *$ & $0.061 * * *$ & $0.400 * * *$ & $-0.081 * * *$ \\
\hline & $(0.033)$ & $(0.013)$ & $(0.006)$ & $(0.015)$ & $(0.026)$ & $(0.006)$ \\
\hline \multirow[t]{2}{*}{ Year of entry 1960-74 } & $0.263^{* * *}$ & $0.257 * * *$ & $0.058 * * *$ & $0.067 * * *$ & $0.540 * * *$ & $-0.110 * * *$ \\
\hline & $(0.033)$ & $(0.025)$ & $(0.005)$ & $(0.010)$ & $(0.026)$ & $(0.008)$ \\
\hline \multirow[t]{2}{*}{ Education } & $0.044 * * *$ & $0.079 * * *$ & $-0.007 * *$ & $-0.022 * * *$ & $0.030 * * *$ & $-0.021 * * *$ \\
\hline & $(0.001)$ & $(0.002)$ & $(0.003)$ & $(0.001)$ & $(0.002)$ & $(0.001)$ \\
\hline \multirow[t]{2}{*}{ Age } & $-0.037 * * *$ & $-0.188 * * *$ & $0.003^{* *}$ & $0.055^{* * *}$ & $0.040 * * *$ & $0.004 * * *$ \\
\hline & $(0.002)$ & $(0.014)$ & $(0.002)$ & $(0.003)$ & $(0.007)$ & $(0.001)$ \\
\hline \multirow[t]{2}{*}{ Female } & $0.005^{* *}$ & $-0.009 *$ & - & - & $-0.418 * * *$ & $0.289 * * *$ \\
\hline & $(0.003)$ & $(0.005)$ & & & $(0.021)$ & $(0.021)$ \\
\hline \multirow[t]{2}{*}{ Black } & $0.059 * * *$ & $0.092 * * *$ & $0.225 * * *$ & 0.050 & $-0.121^{*}$ & 0.055 \\
\hline & $(0.014)$ & $(0.033)$ & $(0.026)$ & $(0.034)$ & $(0.069)$ & $(0.045)$ \\
\hline \multirow[t]{2}{*}{ Other Non White } & $0.028 * *$ & $0.129 * * *$ & $0.069 * *$ & -0.001 & $-0.311 * * *$ & 0.008 \\
\hline & $(0.012)$ & $(0.035)$ & $(0.029)$ & $(0.020)$ & $(0.059)$ & $(0.030)$ \\
\hline \multirow[t]{2}{*}{ Average age of group members in MSA } & $0.005 * * *$ & $0.010 * * *$ & $0.069 * *$ & $-0.002 * *$ & $-0.012 * * *$ & $0.003^{* *}$ \\
\hline & $(0.001)$ & $(0.002)$ & $(0.029)$ & $(0.001)$ & $(0.004)$ & $(0.001)$ \\
\hline \multirow{2}{*}{$\begin{array}{l}\text { Average education of group members in } \\
\text { MSA }\end{array}$} & 0.005 & 0.015 & -0.0002 & $-0.016^{* * *}$ & $0.073 * * *$ & $-0.019 * * *$ \\
\hline & $(0.004)$ & $(0.011)$ & $(0.002)$ & $(0.004)$ & $(0.018)$ & $(0.005)$ \\
\hline $\mathrm{R}^{2}$ & 0.2436 & 0.3588 & 0.0178 & 0.0963 & 0.1435 & 0.1445 \\
\hline $\mathrm{N}$ & 14137 & 5637 & 14293 & 5636 & 22564 & 30584 \\
\hline
\end{tabular}

Note: Standard errors, in parentheses, have been adjusted to reflect within-immigrant-community clustering. Sample consists of foreign-born Census respondents.

*** denotes a coefficient significant at the $1 \%$ level, $* *$ the $5 \%$ level, * the $10 \%$ level. 
Table 3A: Dissimilarity and outcomes: Results with MSA and country-of-origin fixed effects

\begin{tabular}{|c|c|c|c|c|c|c|}
\hline Independent variable & $\begin{array}{c}\text { English Ability } \\
\text { (age 9-18) }\end{array}$ & $\begin{array}{l}\text { Enrollment } \\
\text { (age 16-18) }\end{array}$ & $\begin{array}{l}\text { Single Mother } \\
\text { (age 20-30) }\end{array}$ & $\begin{array}{l}\text { Teen Mother } \\
\text { (age 13-19) }\end{array}$ & $\begin{array}{c}\ln (\text { Earnings }) \\
\text { (age } 20-30)\end{array}$ & $\begin{array}{c}\text { Idle } \\
\text { (age 20-30) }\end{array}$ \\
\hline \multirow[t]{2}{*}{ Dissimilarity index } & 0.017 & -0.021 & -0.035 & 0.041 & $-0.225^{*}$ & $-0.064 * *$ \\
\hline & $(0.036)$ & $(0.069)$ & $(0.046)$ & $(0.046)$ & $(0.120)$ & $(0.033)$ \\
\hline \multirow[t]{2}{*}{ Group share of MSA population } & $-0.201 * * *$ & $0.427 * * *$ & 0.055 & 0.085 & $0.755^{*} * *$ & -0.003 \\
\hline & $(0.071)$ & $(0.170)$ & $(0.180)$ & $(0.123)$ & $(0.293)$ & $(0.099)$ \\
\hline \multirow[t]{2}{*}{ Year of entry $1985-86$} & $0.167 * * *$ & $0.095 * * *$ & $0.017 * *$ & $0.028 *$ & $0.262 * * * *$ & $-0.056 * * *$ \\
\hline & $(0.021)$ & $(0.012)$ & $(0.007)$ & $(0.016)$ & $(0.013)$ & $(0.005)$ \\
\hline \multirow[t]{2}{*}{ Year of entry $1982-84$} & $0.232 * * *$ & $0.220 * * *$ & $0.067 * * *$ & $0.075 * * *$ & $0.263 * * * *$ & $-0.072 * * *$ \\
\hline & $(0.031)$ & $(0.029)$ & $(0.015)$ & $(0.018)$ & $(0.010)$ & () $.005)$ \\
\hline \multirow[t]{2}{*}{ Year of entry $1975-81$} & $0.269 * * *$ & $0.254 * * *$ & $0.037 * * *$ & $0.062 * * *$ & $0.406 * * * *$ & $-0.081 * * *$ \\
\hline & $(0.033)$ & $(0.014)$ & $(0.007)$ & $(0.015)$ & $(0.021)$ & $(.006)$ \\
\hline \multirow[t]{2}{*}{ Year of entry 1960-74 } & $0.265 * * *$ & $0.267 * * *$ & $0.057 * * *$ & $0.066^{* * *}$ & $0.548 * * * *$ & $-0.113 * * *$ \\
\hline & $(0.031)$ & $(0.019)$ & $(0.005)$ & $(0.011)$ & $(0.023)$ & $(0.007)$ \\
\hline \multirow[t]{2}{*}{ Education } & $0.044 * * *$ & $0.078 * * *$ & $-0.007 * *$ & $-0.022 * * *$ & $0.031 * * * *$ & $-0.021 * * *$ \\
\hline & $(0.001)$ & $(0.002)$ & $(0.005)$ & $(0.001)$ & $(0.003)$ & $(0.001)$ \\
\hline \multirow[t]{2}{*}{ Age } & $-0.037 * * *$ & $-0.187 * * *$ & $0.003 * *$ & $0.055^{* * *}$ & $0.041 * * * *$ & $0.004 * * *$ \\
\hline & $(0.002)$ & $(0.015)$ & $(0.001)$ & $(0.004)$ & $(0.007)$ & $(0.001)$ \\
\hline \multirow[t]{2}{*}{ Female } & $0.006 * *$ & -0.009 & - & - & $-0.417 * * * *$ & $0.298 * * *$ \\
\hline & $(0.002)$ & $(0.006)$ & & & $(0.022)$ & $(0.021)$ \\
\hline \multirow[t]{2}{*}{ Black } & $0.055^{* *}$ & -0.058 & $0.187 * * *$ & $0.092 * * *$ & -0.055 & 0.046 \\
\hline & $(0.025)$ & $(0.048)$ & $(0.036)$ & $(0.035)$ & $(0.058)$ & $(0.030)$ \\
\hline \multirow[t]{2}{*}{ Other Non White } & -0.010 & 0.017 & $0.050 * *$ & 0.011 & -0.107 & $-0.030 *$ \\
\hline & $(0.023)$ & $(0.038)$ & $(0.019)$ & $(0.047)$ & $(0.186)$ & $(0.016)$ \\
\hline \multirow[t]{2}{*}{ Average age of group members in MSA } & $-0.002 * *$ & -0.004 & -0.001 & $0.003 *$ & -0.002 & 0.001 \\
\hline & $(0.001)$ & $(0.003)$ & $(0.002)$ & $(0.002)$ & $(0.005)$ & $(0.001)$ \\
\hline \multirow[t]{3}{*}{ Average education of group members in MSA } & 0.004 & 0.008 & -0.008 & -0.009 & 0.032 & -0.003 \\
\hline & $(0.006)$ & $(0.012)$ & $(0.010)$ & $(0.010)$ & $(0.021)$ & $(0.006)$ \\
\hline & 0.2468 & 0.3685 & 0.0264 & 0.0999 & 0.1499 & 0.1482 \\
\hline \multicolumn{7}{|l|}{$\mathrm{R}^{2}$} \\
\hline $\mathrm{N}$ & 14137 & 5637 & 14293 & 5636 & 22564 & 30584 \\
\hline
\end{tabular}

Note: Standard errors, in parentheses, have been adjusted to reflect within-immigrant-community clustering. Sample consists of foreign-born Census respondents.

$* * *$ denotes a coefficient significant at the $1 \%$ level, $* *$ the $5 \%$ level, * the $10 \%$ level. 
Table 3B: Isolation and outcomes: Results with MSA and country-of-origin fixed effects

\begin{tabular}{|c|c|c|c|c|c|c|}
\hline Independent variable & $\begin{array}{l}\text { English Ability } \\
\text { (age 9-18) }\end{array}$ & $\begin{array}{l}\text { Enrollment } \\
\text { (age 16-18) }\end{array}$ & $\begin{array}{l}\text { Single Mother } \\
\text { (age 20-30) }\end{array}$ & $\begin{array}{l}\text { Teen Mother } \\
\text { (age 13-19) }\end{array}$ & $\begin{array}{c}\ln (\text { Earnings }) \\
\text { (age 20-30) }\end{array}$ & $\begin{array}{c}\text { Idle } \\
\text { (age 20-30) }\end{array}$ \\
\hline \multirow[t]{2}{*}{ Isolation index } & $0.232 * *$ & -0.188 & -0.268 & -0.064 & 0.250 & 0.133 \\
\hline & $(0.107)$ & $(0.202)$ & $(0.178)$ & $(0.157)$ & $(0.512)$ & $(0.204)$ \\
\hline \multirow[t]{2}{*}{ Group share of MSA population } & $-0.348 * * *$ & $0.614 * * *$ & 0.241 & 0.095 & 0.709 & -0.053 \\
\hline & $(0.085)$ & $(0.195)$ & $(0.154)$ & $(0.122)$ & $(0.515)$ & $(0.161)$ \\
\hline \multirow[t]{2}{*}{ Year of entry $1985-86$} & $0.167 * * *$ & $0.095 * * *$ & $0.017 * *$ & $0.028^{*}$ & $0.262 * * *$ & $-0.056^{* * *}$ \\
\hline & $(0.021)$ & $(0.012)$ & $(0.007)$ & $(0.016)$ & $(0.013)$ & $(0.005)$ \\
\hline \multirow[t]{2}{*}{ Year of entry $1982-84$} & $0.232 * * *$ & $0.220 * * *$ & $0.067 * * *$ & $0.075 * * *$ & $0.263 * * *$ & $-0.072 * * *$ \\
\hline & $(0.031)$ & $(0.029)$ & $(0.015)$ & $(0.018)$ & $(0.010)$ & $(0.005)$ \\
\hline \multirow[t]{2}{*}{ Year of entry $1975-81$} & $0.269 * * *$ & $0.254^{* * *}$ & $0.037 * * *$ & $0.062 * * *$ & $0.406^{* * *}$ & $-0.080 * * *$ \\
\hline & $(0.033)$ & $(0.014)$ & $(0.007)$ & $(0.015)$ & $(0.021)$ & $(0.006)$ \\
\hline \multirow[t]{2}{*}{ Year of entry 1960-74 } & $0.265^{* * *}$ & $0.267 * * *$ & $0.057 * * *$ & $0.066^{* * *}$ & $0.548^{* * *}$ & $-0.113^{* * *}$ \\
\hline & $(0.031)$ & $(0.019)$ & $(0.005)$ & $(0.011)$ & $(0.023)$ & $(0.007)$ \\
\hline \multirow[t]{2}{*}{ Education } & $0.044 * * *$ & $0.078 * * *$ & $-0.007 * *$ & $-0.022 * * *$ & $0.031 * * *$ & $-0.021 * * *$ \\
\hline & $(0.001)$ & $(0.002)$ & $(0.003)$ & $(0.001)$ & $(0.003)$ & $(0.001)$ \\
\hline \multirow[t]{2}{*}{ Age } & $-0.037 * * *$ & $-0.187 * * *$ & $0.003 * *$ & $0.055^{* * *}$ & $0.041 * * *$ & $0.004 * * *$ \\
\hline & $(0.002)$ & $(0.015)$ & $(0.001)$ & $(0.004)$ & $(0.007)$ & $(0.001)$ \\
\hline \multirow[t]{2}{*}{ Female } & $0.006^{* *}$ & -0.009 & - & - & $-0.417 * * *$ & $0.289 * * *$ \\
\hline & $(0.002)$ & $(0.006)$ & & & $(0.022)$ & $(0.021)$ \\
\hline \multirow[t]{2}{*}{ Black } & $0.055 * *$ & -0.058 & $0.187 * * *$ & $0.092 * * *$ & -0.054 & 0.046 \\
\hline & $(0.025)$ & $(0.048)$ & $(0.036)$ & $(0.035)$ & $(0.058)$ & $(0.030)$ \\
\hline \multirow[t]{2}{*}{ Other Non White } & -0.010 & 0.017 & $0.050^{* *}$ & 0.011 & -0.108 & $-0.031 *$ \\
\hline & $(0.022)$ & $(0.038)$ & $(0.019)$ & $(0.047)$ & $(0.186)$ & $(0.016)$ \\
\hline \multirow[t]{2}{*}{ Average age of group members in MSA } & $-0.002 * * *$ & -0.004 & -0.001 & $0.003 *$ & -0.002 & 0.001 \\
\hline & $(0.001)$ & $(0.003)$ & $(0.002)$ & $(0.002)$ & $(0.005)$ & $(0.001)$ \\
\hline \multirow[t]{2}{*}{ Average education of group members in MSA } & $0.009 *$ & 0.004 & -0.013 & -0.011 & $0.044 *$ & 0.002 \\
\hline & $(0.005)$ & $(0.013)$ & $(0.010)$ & $(0.011)$ & $(0025)$ & $(0.006)$ \\
\hline $\mathrm{R}^{2}$ & 0.2468 & 0.3685 & 0.0264 & 0.0999 & 0.1499 & 0.1482 \\
\hline $\mathrm{N}$ & 14137 & 5637 & 14293 & 5636 & 22564 & 30584 \\
\hline
\end{tabular}

Note: Standard errors, in parentheses, have been adjusted to reflect within-immigrant-community clustering. Sample consists of foreign-born Census

respondents.

$* * *$ denotes a coefficient significant at the $1 \%$ level, $* *$ the $5 \%$ level, * the $10 \%$ level. 
Table 4A: Dissimilarity and outcomes: Results from Instrumental Variable specifications

\begin{tabular}{|c|c|c|c|c|c|c|}
\hline Independent variable & $\begin{array}{c}\text { English Ability } \\
\text { (age 9-18) }\end{array}$ & $\begin{array}{l}\text { Enrollment } \\
\text { (age 16-18) }\end{array}$ & $\begin{array}{l}\text { Single Mother } \\
\text { (age 20-30) }\end{array}$ & $\begin{array}{l}\text { Teen Mother } \\
\text { (age 13-19) }\end{array}$ & $\begin{array}{c}\ln (\text { Earnings }) \\
\text { (age } 20-30)\end{array}$ & $\begin{array}{c}\text { Idle } \\
\text { (age 20-30) }\end{array}$ \\
\hline \multirow[t]{2}{*}{ Dissimilarity index } & $0.104 * *$ & 0.067 & 0.035 & 0.008 & $0.371 * *$ & 0.047 \\
\hline & $(0.045)$ & $(0.108)$ & $(0.052)$ & $(0.064)$ & $(0.170)$ & $(0.044)$ \\
\hline \multirow[t]{2}{*}{ Group share of MSA population } & $-0.136^{*}$ & $0.555^{* * *}$ & 0.090 & 0.064 & $1.062 * * *$ & 0.058 \\
\hline & $(0.070)$ & $(0.195)$ & $(0.189)$ & $(0.125)$ & $(0.403)$ & $(0.116)$ \\
\hline \multirow[t]{2}{*}{ Year of entry $1985-86$} & $0.167 * * *$ & $0.095 * * *$ & $0.017 * *$ & $0.028 *$ & $0.263 * * *$ & $-0.056 * * *$ \\
\hline & $(0.021)$ & $(0.012)$ & $(0.007)$ & $(0.016)$ & $(0.013)$ & $(0.005)$ \\
\hline \multirow[t]{2}{*}{ Year of entry $1982-84$} & $0.232 * * *$ & $0.220 * * *$ & $0.067 * * *$ & $0.075^{* * *}$ & $0.263 * * *$ & $-0.072 * * *$ \\
\hline & $(0.031)$ & $(0.029)$ & $(0.015)$ & $(0.018)$ & $(0.010)$ & $(0.005)$ \\
\hline \multirow[t]{2}{*}{ Year of entry $1975-81$} & $0.269 * * *$ & $0.254 * * *$ & $0.037 * * *$ & $0.062 * * *$ & $0.406^{* * *}$ & $-0.080 * * *$ \\
\hline & $(0.033)$ & $(0.014)$ & $(0.007)$ & $(0.015)$ & $(0.021)$ & $(0.006)$ \\
\hline \multirow[t]{2}{*}{ Year of entry 1960-74 } & $0.265 * * *$ & $0.267 * * *$ & $0.057 * * *$ & $0.066^{* * *}$ & $0.548 * * *$ & $-0.113 * * *$ \\
\hline & $(0.031)$ & $(0.019)$ & $(0.005)$ & $(0.011)$ & $(0.023)$ & $(0.007)$ \\
\hline \multirow[t]{2}{*}{ Education } & $0.044 * * *$ & $0.078 * * *$ & $0.003 * *$ & $0.055 * * *$ & $0.031 * * *$ & $0.004 * * *$ \\
\hline & $(0.001)$ & $(0.002)$ & $(0.001)$ & $(0.004)$ & $(0.003)$ & $(0.001)$ \\
\hline \multirow[t]{2}{*}{ Age } & $-0.037 * * *$ & $-0.187 * * *$ & $-0.007 * *$ & $-0.022 * * *$ & $0.041 * * *$ & $-0.021 * * *$ \\
\hline & $(0.002)$ & $(0.015)$ & $(0.003)$ & $(0.001)$ & $(0.007)$ & $(0.001)$ \\
\hline \multirow[t]{2}{*}{ Female } & $0.006^{* *}$ & -0.009 & - & - & $-0.417 * * *$ & $0.289 * * *$ \\
\hline & $(0.002)$ & $(0.006)$ & & & $(0.022)$ & $(0.021)$ \\
\hline \multirow[t]{2}{*}{ Black } & $0.054 * *$ & -0.058 & $0.187 * * *$ & $0.092 * * *$ & -0.054 & 0.046 \\
\hline & $(0.025)$ & $(0.048)$ & $(0.036)$ & $(0.035)$ & $(0.058)$ & $(0.030)$ \\
\hline \multirow[t]{2}{*}{ Other Non White } & -0.011 & 0.016 & $0.050 * *$ & 0.011 & -0.109 & $-0.031 *$ \\
\hline & $(0.022)$ & $(0.038)$ & $(0.019)$ & $(0.047)$ & $(0.186)$ & $(0.16)$ \\
\hline \multirow[t]{2}{*}{ Average age of group members in MSA } & $-0.001 *$ & -0.004 & -0.001 & $0.003 *$ & -0.001 & -0.0001 \\
\hline & $(0.001)$ & $(0.003)$ & $(0.002)$ & $(0.002)$ & $(0.005)$ & $(0.007)$ \\
\hline \multirow[t]{2}{*}{ Average education of group members in MSA } & 0.007 & 0.010 & -0.006 & -0.010 & $0.047^{*}$ & 0.001 \\
\hline & $(0.007)$ & $(0.013)$ & $(0.010)$ & $(0.012)$ & $(0.026)$ & $(0.001)$ \\
\hline $\mathrm{R}^{2}$ & 0.2468 & 0.3684 & 0.0264 & 0.0999 & 0.1498 & 0.1482 \\
\hline $\mathrm{N}$ & 14137 & 5637 & 14293 & 5636 & 22564 & 30584 \\
\hline
\end{tabular}

Note: Standard errors, in parentheses, have been adjusted to reflect within-immigrant-community clustering. Sample consists of foreign-born Census

respondents.

$* * *$ denotes a coefficient significant at the $1 \%$ level, $* *$ the $5 \%$ level, * the $10 \%$ level. 
Table 4B: Isolation and outcomes: Results from Instrumental Variable specifications

\begin{tabular}{|c|c|c|c|c|c|c|}
\hline Independent variable & $\begin{array}{c}\text { English Ability } \\
\text { (age 9-18) }\end{array}$ & $\begin{array}{l}\text { Enrollment } \\
\text { (age 16-18) }\end{array}$ & $\begin{array}{l}\text { Single Mother } \\
\text { (age 20-30) }\end{array}$ & $\begin{array}{l}\text { Teen Mother } \\
\text { (age 13-19) }\end{array}$ & $\begin{array}{c}\ln (\text { Earnings }) \\
\text { (age } 20-30)\end{array}$ & $\begin{array}{c}\text { Idle } \\
\text { (age 20-30) }\end{array}$ \\
\hline \multirow[t]{2}{*}{ Isolation index } & $0.970 * *$ & 0.506 & 0.283 & 0.059 & $2.963 * *$ & 0.388 \\
\hline & $(0.402)$ & $(0.813)$ & $(0.416)$ & $(0.494)$ & $(1.525)$ & $(0.361)$ \\
\hline \multirow[t]{2}{*}{ Group share of MSA population } & $-0.771 * * *$ & 0.204 & -0.106 & 0.026 & -1.052 & -0.218 \\
\hline & $(0.237)$ & $(0.495)$ & $(0.298)$ & $(0.316)$ & $(0.930)$ & $(0.254)$ \\
\hline \multirow[t]{2}{*}{ Year of entry $1985-86$} & $0.167 * * *$ & $0.095 * * *$ & $0.017 * *$ & $0.028^{*}$ & $0.262 * * *$ & $-0.056 * * *$ \\
\hline & $(0.021)$ & $(0.012)$ & $(0.007)$ & $(0.016)$ & $(0.013)$ & $(0.005)$ \\
\hline \multirow[t]{2}{*}{ Year of entry 1982-84 } & $0.232 * * *$ & $0.220 * * *$ & $0.067 * * *$ & $0.075 * * *$ & $0.263 * * *$ & $-0.072 * * *$ \\
\hline & $(0.031)$ & $(0.030)$ & $(0.015)$ & $(0.018)$ & $(0.010)$ & $(0.005)$ \\
\hline \multirow[t]{2}{*}{ Year of entry $1975-81$} & $0.269 * * *$ & $0.254 * * *$ & $0.037 * * *$ & $0.062 * * *$ & $0.406 * * *$ & $-0.080 * * *$ \\
\hline & $(0.033)$ & $(0.014)$ & $(0.007)$ & $(0.015)$ & $(0.021)$ & $(0.006)$ \\
\hline \multirow[t]{2}{*}{ Year of entry 1960-74 } & $0.266^{* * *}$ & $0.267 * * *$ & $0.057 * * *$ & $0.066^{* * *}$ & $0.549 * * *$ & $-0.113 * * *$ \\
\hline & $(0.031)$ & (0.019) & $(0.005)$ & ()011) & $(0.023)$ & $(0.007)$ \\
\hline \multirow[t]{2}{*}{ Education } & $0.044 * * *$ & $0.078 * * *$ & $0.003 * *$ & $0.055 * * *$ & $0.031 * * *$ & $0.004 * * *$ \\
\hline & $(0.001)$ & $(0.002)$ & $(0.001)$ & $(0.004)$ & $(0.003)$ & $(0.001)$ \\
\hline \multirow[t]{2}{*}{ Age } & $-0.037 * * *$ & $-0.187 * * *$ & $-0.007 * *$ & $-0.022 * * *$ & $0.041 * * *$ & $-0.021 * * *$ \\
\hline & $(0.002)$ & $(0.015)$ & $(0.003)$ & $(0.001)$ & $(0.007)$ & $(0.001)$ \\
\hline \multirow[t]{2}{*}{ Female } & $0.006^{* *}$ & -0.009 & & & $-0.417 * * *$ & $0.289 * * *$ \\
\hline & $(0.002)$ & $(0.006)$ & & & $(0.022)$ & $(0.021)$ \\
\hline \multirow[t]{2}{*}{ Black } & $0.055 * *$ & -0.058 & $0.187 * * *$ & $0.092 * * *$ & -0.055 & 0.046 \\
\hline & $(0.025)$ & $(0.048)$ & $(.036)$ & $(0.035)$ & $(0.058)$ & $(0.030)$ \\
\hline \multirow[t]{2}{*}{ Other Non White } & -0.011 & 0.017 & $0.050 * *$ & 0.011 & -0.111 & $-0.031 *$ \\
\hline & $(0.023)$ & $(0.038)$ & $(0.020)$ & $(0.047)$ & $(0.185)$ & $(0.016)$ \\
\hline \multirow[t]{2}{*}{ Average age of group members in MSA } & $-0.003 * * *$ & -0.004 & -0.001 & 0.003 & -0.004 & 0.001 \\
\hline & $(0.001)$ & $(0.003)$ & $(0.002)$ & $(0.002)$ & $(0.006)$ & $(0.001)$ \\
\hline \multirow[t]{2}{*}{ Average education of group members in MSA } & $0.027 * *$ & 0.021 & -0.00002 & -0.008 & 0.111 & 0.008 \\
\hline & $(0.012)$ & $(0025)$ & $(0.015)$ & $(0.019)$ & $(0.047)$ & $(0.011)$ \\
\hline $\mathrm{R}^{2}$ & 0.2467 & 0.3684 & 0.0263 & 0.0999 & 0.1497 & 0.1482 \\
\hline $\mathrm{N}$ & 14137 & 5637 & 14293 & 5636 & 22564 & 30584 \\
\hline
\end{tabular}

Note: Standard errors, in parentheses, have been adjusted to reflect within-immigrant-community clustering. Sample consists of foreign-born Census respondents.

$* * *$ denotes a coefficient significant at the $1 \%$ level, $* *$ the $5 \%$ level, * the $10 \%$ level. 
Table 5: Tract-level group share and outcomes: Results with MSA and country-of-origin fixed effects

\begin{tabular}{|c|c|c|c|c|}
\hline Independent variable & $\begin{array}{c}\text { English Ability } \\
\text { (age 9-18) }\end{array}$ & $\begin{array}{l}\text { Enrollment } \\
\text { (age 16-18) }\end{array}$ & $\begin{array}{l}\ln \text { (Earnings) } \\
\text { (age } 20-30)\end{array}$ & $\begin{array}{c}\text { Idle } \\
\text { (age 20-30) }\end{array}$ \\
\hline \multirow[t]{2}{*}{ Group share of tract population } & $-0.076 * * *$ & $0.038 * * *$ & $-0.195 * * *$ & $0.048 * * *$ \\
\hline & $(0.006)$ & $(0.006)$ & $(0.033)$ & $(0.006)$ \\
\hline \multirow{2}{*}{$\begin{array}{l}\text { Group share of MSA } \\
\text { population }\end{array}$} & 0.027 & 0.057 & $0.199 * *$ & $-0.070 * *$ \\
\hline & $(0.024)$ & $(0.069)$ & $(0.082)$ & $(0.033)$ \\
\hline \multirow[t]{2}{*}{ Year of entry $1985-86$} & $0.180 * * *$ & $0.120 * * *$ & $0.274 * * *$ & $-0.052 * * *$ \\
\hline & $(0.017)$ & $(0.002)$ & $(0.011)$ & $(0.004)$ \\
\hline \multirow[t]{2}{*}{ Year of entry 1982-84 } & $0.228 * * *$ & $0.186 * * *$ & $0.328 * * *$ & $-0.068 * * *$ \\
\hline & $(0.025)$ & $(0.008)$ & $(0.008)$ & $(0.005)$ \\
\hline \multirow[t]{2}{*}{ Year of entry $1980-81$} & $0.241 * * *$ & $0.236 * * *$ & $0.378 * * *$ & $-0.093 * * *$ \\
\hline & $(0.023)$ & $(0.019)$ & $(0.017)$ & $(0.003)$ \\
\hline \multirow[t]{2}{*}{ Year of entry 1975-79 } & $0.273 * * *$ & $0.257 * * *$ & $0.444 * * *$ & $-0.098 * * *$ \\
\hline & $(0.023)$ & $(0.012)$ & $(0.020)$ & $(0.003)$ \\
\hline \multirow[t]{2}{*}{ Year of entry $1970-74$} & $0.278 * * *$ & $0.228 * * * *$ & $0.504 * * *$ & $-0.098 * * *$ \\
\hline & $(0.023)$ & $(0.014)$ & $(0.026)$ & $(0.002)$ \\
\hline \multirow[t]{2}{*}{ Year of entry 1965-69 } & --- & --- & $0.592 * * *$ & $-0.094 * * *$ \\
\hline & & & $(0.029)$ & $(0.005)$ \\
\hline \multirow[t]{2}{*}{ Year of entry 1960-64 } & --- & --- & $0.713 * * *$ & $-0.095 * * *$ \\
\hline & & & $(0.042)$ & $(0.003)$ \\
\hline \multirow[t]{2}{*}{ Education } & $0.041 * * *$ & $0.079 * * *$ & $0.029 * * *$ & $-0.021 * * *$ \\
\hline & $(0.001)$ & $(0.003)$ & $(0.002)$ & $(0.001)$ \\
\hline \multirow[t]{2}{*}{ Age } & $-0.032 * * *$ & $-0.169 * * *$ & $0.043 * * *$ & $0.002 * * *$ \\
\hline & $(0.001)$ & $(0.003)$ & $(0.005)$ & $(0.001)$ \\
\hline \multirow[t]{2}{*}{ Female } & $-0.005^{* * *}$ & -0.002 & $-0.397 * * *$ & $0.286^{* * *}$ \\
\hline & $(0.001)$ & $(0.003)$ & $(0.015)$ & $(0.018)$ \\
\hline \multirow[t]{2}{*}{ Black } & $0.011^{*}$ & -0.006 & -0.025 & $0.025 * *$ \\
\hline & $(0.007)$ & $(0.016)$ & $(0.046)$ & $(0.013)$ \\
\hline \multirow[t]{2}{*}{ Other Non White } & $-0.026^{*}$ & -0.033 & -0.006 & $-0.007 * *$ \\
\hline & $(0.016)$ & $(0.032)$ & $(0.024)$ & $(0.003)$ \\
\hline \multirow{2}{*}{$\begin{array}{l}\text { Average age of group members } \\
\text { in MSA }\end{array}$} & -0.00001 & -0.001 & -0.001 & $0.002 *$ \\
\hline & $(0.0004)$ & $(0.001)$ & $(0.001)$ & $(0.001)$ \\
\hline \multirow{2}{*}{$\begin{array}{l}\text { Average education of group } \\
\text { members in MSA }\end{array}$} & $0.003 *$ & $0.018 * * *$ & $0.051 * * *$ & -0.004 \\
\hline & $(0.002)$ & $(0.006)$ & $(0.012)$ & $(0.003)$ \\
\hline $\mathrm{R}^{2}$ & 0.2242 & 0.3064 & 0.1452 & 0.1449 \\
\hline $\mathrm{N}$ & 193,916 & 99,235 & 408,897 & 552,513 \\
\hline
\end{tabular}

Note: Standard errors, in parentheses, have been adjusted to reflect within group/tract clustering. Sample consists of foreign-born Census respondents.

$* * *$ denotes a coefficient significant at the $1 \%$ level, ** the $5 \%$ level, * the $10 \%$ level. 
Table 6: Tract-level group share and outcomes: Instrumental Variable specifications

\begin{tabular}{|c|c|c|c|c|}
\hline Independent variable & $\begin{array}{l}\text { English Ability } \\
\text { (age 9-18) }\end{array}$ & $\begin{array}{l}\text { Enrollment } \\
\text { (age 16-18) }\end{array}$ & $\begin{array}{l}\ln (\text { Earnings }) \\
\text { (age 20-30) }\end{array}$ & $\begin{array}{c}\text { Idle } \\
\text { (age 20-30) }\end{array}$ \\
\hline Group share of tract population & $\begin{array}{c}-0.103 * * * \\
(0.012)\end{array}$ & $\begin{array}{l}0.030 \\
(0.020)\end{array}$ & $\begin{array}{c}-0.274 * * * \\
(0.054)\end{array}$ & $\begin{array}{c}0.003 \\
(0.027)\end{array}$ \\
\hline $\begin{array}{l}\text { Group share of MSA } \\
\text { population }\end{array}$ & $\begin{array}{l}0.055 * * \\
(0.026)\end{array}$ & $\begin{array}{c}0.065 \\
(0.072)\end{array}$ & $\begin{array}{l}0.199 * * \\
(0.082)\end{array}$ & $\begin{array}{l}-0.025 \\
(0.042)\end{array}$ \\
\hline Year of entry 1985-86 & $\begin{array}{c}0.180 * * * \\
(0.017)\end{array}$ & $\begin{array}{c}0.120 * * * \\
(0.002)\end{array}$ & $\begin{array}{c}0.274 * * * \\
(0.011)\end{array}$ & $\begin{array}{c}-0.052 * * * \\
(0.004)\end{array}$ \\
\hline Year of entry $1982-84$ & $\begin{array}{l}0.228 * * * \\
(0.025)\end{array}$ & $\begin{array}{c}0.186 * * * \\
(0.008)\end{array}$ & $\begin{array}{l}0.328 * * * \\
(0.008)\end{array}$ & $\begin{array}{c}-0.068^{* * *} \\
(0.005)\end{array}$ \\
\hline Year of entry $1980-81$ & $\begin{array}{c}0.242 * * * \\
(0.023)\end{array}$ & $\begin{array}{c}0.236 * * * \\
(0.019)\end{array}$ & $\begin{array}{c}0.378 * * * \\
(0.017)\end{array}$ & $\begin{array}{c}-0.093 * * * \\
(0.003)\end{array}$ \\
\hline Year of entry $1975-79$ & $\begin{array}{c}0.273 * * * \\
(0.023)\end{array}$ & $\begin{array}{c}0.257 * * * \\
(0.012)\end{array}$ & $\begin{array}{c}0.444 * * * \\
(0.020)\end{array}$ & $\begin{array}{c}-0.098 * * * \\
(0.003)\end{array}$ \\
\hline Year of entry $1970-74$ & $\begin{array}{l}0.278 * * * \\
(0.023)\end{array}$ & $\begin{array}{l}0.228 * * * * \\
(0.014)\end{array}$ & $\begin{array}{l}0.505 * * * \\
(0.026)\end{array}$ & $\begin{array}{c}-0.098 * * * \\
(0.003)\end{array}$ \\
\hline Year of entry 1965-69 & --- & --- & $\begin{array}{c}0.591 * * * \\
(0.029)\end{array}$ & $\begin{array}{c}-0.094 * * * \\
(0.005)\end{array}$ \\
\hline Year of entry 1960-64 & --- & --- & $\begin{array}{c}0.710 * * * \\
(0.042)\end{array}$ & $\begin{array}{c}-0.096^{* * *} \\
(0.004)\end{array}$ \\
\hline Education & $\begin{array}{c}0.041 * * * \\
(0.001)\end{array}$ & $\begin{array}{c}0.079 * * * \\
(0.003)\end{array}$ & $\begin{array}{c}0.029 * * * \\
(0.002)\end{array}$ & $\begin{array}{c}-0.021 * * * \\
(0.001)\end{array}$ \\
\hline Age & $\begin{array}{c}-0.032 * * * \\
(0.001)\end{array}$ & $\begin{array}{c}-0.169 * * * \\
(0.003)\end{array}$ & $\begin{array}{c}0.043 * * * \\
(0.005)\end{array}$ & $\begin{array}{c}0.002 * * * \\
(0.001)\end{array}$ \\
\hline Female & $\begin{array}{c}-0.005^{* * *} \\
(0.001)\end{array}$ & $\begin{array}{l}-0.002 \\
(0.003)\end{array}$ & $\begin{array}{c}-0.397 * * * \\
(0.015)\end{array}$ & $\begin{array}{c}0.286 * * * \\
(0.017)\end{array}$ \\
\hline Black & $\begin{array}{l}0.010^{*} \\
(0.006)\end{array}$ & $\begin{array}{l}-0.006 \\
(0.016)\end{array}$ & $\begin{array}{l}-0.026 \\
(0.045)\end{array}$ & $\begin{array}{l}0.023 * * \\
(0.012)\end{array}$ \\
\hline Other Non White & $\begin{array}{l}-0.026 \\
(0.016)\end{array}$ & $\begin{array}{l}-0.033 \\
(0.032)\end{array}$ & $\begin{array}{l}-0.004 \\
(0.023)\end{array}$ & $\begin{array}{l}-0.005 * * \\
(0.004)\end{array}$ \\
\hline $\begin{array}{l}\text { Average age of group members } \\
\text { in MSA }\end{array}$ & $\begin{array}{c}-0.000001 \\
(0.0004)\end{array}$ & $\begin{array}{l}-0.001 \\
(0.001)\end{array}$ & $\begin{array}{l}-0.001 \\
(0.001)\end{array}$ & $\begin{array}{l}0.002 * \\
(0.001)\end{array}$ \\
\hline $\begin{array}{l}\text { Average education of group } \\
\text { members in MSA }\end{array}$ & $\begin{array}{l}0.003^{*} \\
(0.002)\end{array}$ & $\begin{array}{c}0.018 * * * \\
(0.006)\end{array}$ & $\begin{array}{c}0.051 * * * \\
(0.012)\end{array}$ & $\begin{array}{l}-0.004 \\
(0.003)\end{array}$ \\
\hline $\mathrm{R}^{2}$ & 0.2241 & 0.3064 & 0.1451 & 0.1447 \\
\hline $\mathrm{N}$ & 193,916 & 99,235 & 408,897 & 552,513 \\
\hline
\end{tabular}


Table 7: Testing for heterogeneity in the effects of segregation

\begin{tabular}{|c|c|c|c|c|c|c|c|c|}
\hline \multirow{3}{*}{$\begin{array}{l}\text { Dependent } \\
\text { variable }\end{array}$} & \multicolumn{4}{|c|}{ Dissimilarity } & \multicolumn{4}{|c|}{ Isolation } \\
\hline & \multicolumn{2}{|c|}{ OLS/Fixed Effects } & \multicolumn{2}{|c|}{ IV } & \multicolumn{2}{|c|}{ OLS/Fixed Effects } & \multicolumn{2}{|c|}{ IV } \\
\hline & Main effect & Interaction & Main effect & Interaction & Main effect & Interaction & Main effect & Interaction \\
\hline $\begin{array}{l}\text { English } \\
\text { Ability }\end{array}$ & $\begin{array}{l}0.207 * \\
(0.109)\end{array}$ & $\begin{array}{l}-0.021 * \\
(0.012)\end{array}$ & $\begin{array}{l}-0.254 \\
(0.154)\end{array}$ & $\begin{array}{c}0.041 * * \\
(0.018)\end{array}$ & $\begin{array}{c}0.239 \\
(0.448)\end{array}$ & $\begin{array}{l}-0.001 \\
(0.051)\end{array}$ & $\begin{array}{c}-2.770 * * \\
(1.214)\end{array}$ & $\begin{array}{c}0.350 * * \\
(0.138)\end{array}$ \\
\hline $\begin{array}{l}\text { School } \\
\text { Enrollment }\end{array}$ & $\begin{array}{l}-0.115 \\
(0.333)\end{array}$ & $\begin{array}{c}0.011 \\
(0.036)\end{array}$ & $\begin{array}{l}-0.208 \\
(0.370)\end{array}$ & $\begin{array}{c}0.033 \\
(0.045)\end{array}$ & $\begin{array}{l}0.852 \\
(1.00)\end{array}$ & $\begin{array}{l}-0.130 \\
(0.116)\end{array}$ & $\begin{array}{l}-1.950 \\
(2.579)\end{array}$ & $\begin{array}{c}0.239 \\
(0.293)\end{array}$ \\
\hline $\begin{array}{l}\text { Single } \\
\text { Mother }\end{array}$ & $\begin{array}{c}0.112 \\
(0.223)\end{array}$ & $\begin{array}{c}-0.016 \\
(0.021)\end{array}$ & $\begin{array}{c}0.564 * * \\
(0.209)\end{array}$ & $\begin{array}{c}-0.064 * * \\
(0.026)\end{array}$ & $\begin{array}{c}0.939 \\
(1.067)\end{array}$ & $\begin{array}{c}-0.146 \\
(0.121)\end{array}$ & $\begin{array}{c}3.399 * * \\
(1.482)\end{array}$ & $\begin{array}{c}-0.297 * \\
(0.157)\end{array}$ \\
\hline $\begin{array}{l}\text { Teen } \\
\text { Mother }\end{array}$ & $\begin{array}{c}0.025 \\
(0.200)\end{array}$ & $\begin{array}{c}0.002 \\
(0.022)\end{array}$ & $\begin{array}{c}0.352 \\
(0.266)\end{array}$ & $\begin{array}{l}-0.041 \\
(0.033)\end{array}$ & $\begin{array}{l}-0.755 \\
(0.886)\end{array}$ & $\begin{array}{c}0.084 \\
(0.099)\end{array}$ & $\begin{array}{c}2.156 \\
(1.968)\end{array}$ & $\begin{array}{l}-0.205 \\
(0.217)\end{array}$ \\
\hline $\ln$ (earnings) & $\begin{array}{c}0.216 \\
(0.544)\end{array}$ & $\begin{array}{l}-0.049 \\
(0.058)\end{array}$ & $\begin{array}{c}-1.571 * * * \\
(0.589)\end{array}$ & $\begin{array}{c}0.238 * * * \\
(0.080)\end{array}$ & $\begin{array}{l}2.965 * \\
(1.600)\end{array}$ & $\begin{array}{l}-0.331 * \\
(0.183)\end{array}$ & $\begin{array}{c}-14.021 * * * \\
(5.212)\end{array}$ & $\begin{array}{c}1.637 * * * \\
(0.568)\end{array}$ \\
\hline Idle & $\begin{array}{l}-0.099 \\
(0.192)\end{array}$ & $\begin{array}{c}0.004 \\
(0.020)\end{array}$ & $\begin{array}{c}-0.048 \\
(0.141)\end{array}$ & $\begin{array}{c}0.012 \\
(0.017)\end{array}$ & $\begin{array}{c}0.587 \\
(0.840)\end{array}$ & $\begin{array}{l}-0.055 \\
(0.094)\end{array}$ & $\begin{array}{l}-0.740 \\
(0.920)\end{array}$ & $\begin{array}{c}0.108 \\
(0.102)\end{array}$ \\
\hline
\end{tabular}

Note: Main effect is the coefficient on the relevant segregation index in each specification. Interaction term is between segregation and the mean education level of immigrants of the same nationality within the same metropolitan area. Standard errors, corrected for within MSA/group clustering, in parentheses.

$* * *$ denotes a coefficient significant at the $1 \%$ level, $* *$ the $5 \%$ level, $*$ the $10 \%$ level. 
Table 8: Testing for heterogeneity in the effect of tract share

\begin{tabular}{lccccc}
\hline \multirow{2}{*}{$\begin{array}{l}\text { Dependent } \\
\text { variable }\end{array}$} & \multicolumn{2}{c}{ OLS/Fixed Effects } & \multicolumn{2}{c}{ IV } \\
\cline { 2 - 3 } \cline { 5 - 6 } English Ability & Main effect & Interaction & & Main effect & Interaction \\
\cline { 5 - 6 } & $-0.285^{* * *}$ & $0.038^{* * *}$ & & $-0.234 * * *$ & $0.024^{* * *}$ \\
School & $(0.031)$ & $(0.006)$ & & $(0.012)$ & $(0.008)$ \\
Enrollment & $0.090^{*}$ & -0.010 & & 0.018 & 0.002 \\
ln(earnings) & $(0.053)$ & $(0.010)$ & & $(0.073)$ & $(0.012)$ \\
& -0.008 & -0.034 & & $-0.623 * * *$ & $0.063 * *$ \\
Idle & $(0.168)$ & $(0.029)$ & & $(0.222)$ & $(0.032)$ \\
& $0.088^{* *}$ & -0.007 & $0.210^{*}$ & $-0.038^{* *}$ \\
\hline
\end{tabular}

Note: Main effect is the coefficient on the relevant segregation index in each specification. Interaction term is between segregation and the mean education level of immigrants of the same nationality within the same metropolitan area. Standard errors, corrected for withintract/group clustering, in parentheses.

*** denotes a coefficient significant at the $1 \%$ level, ** the $5 \%$ level, * the $10 \%$ level. 


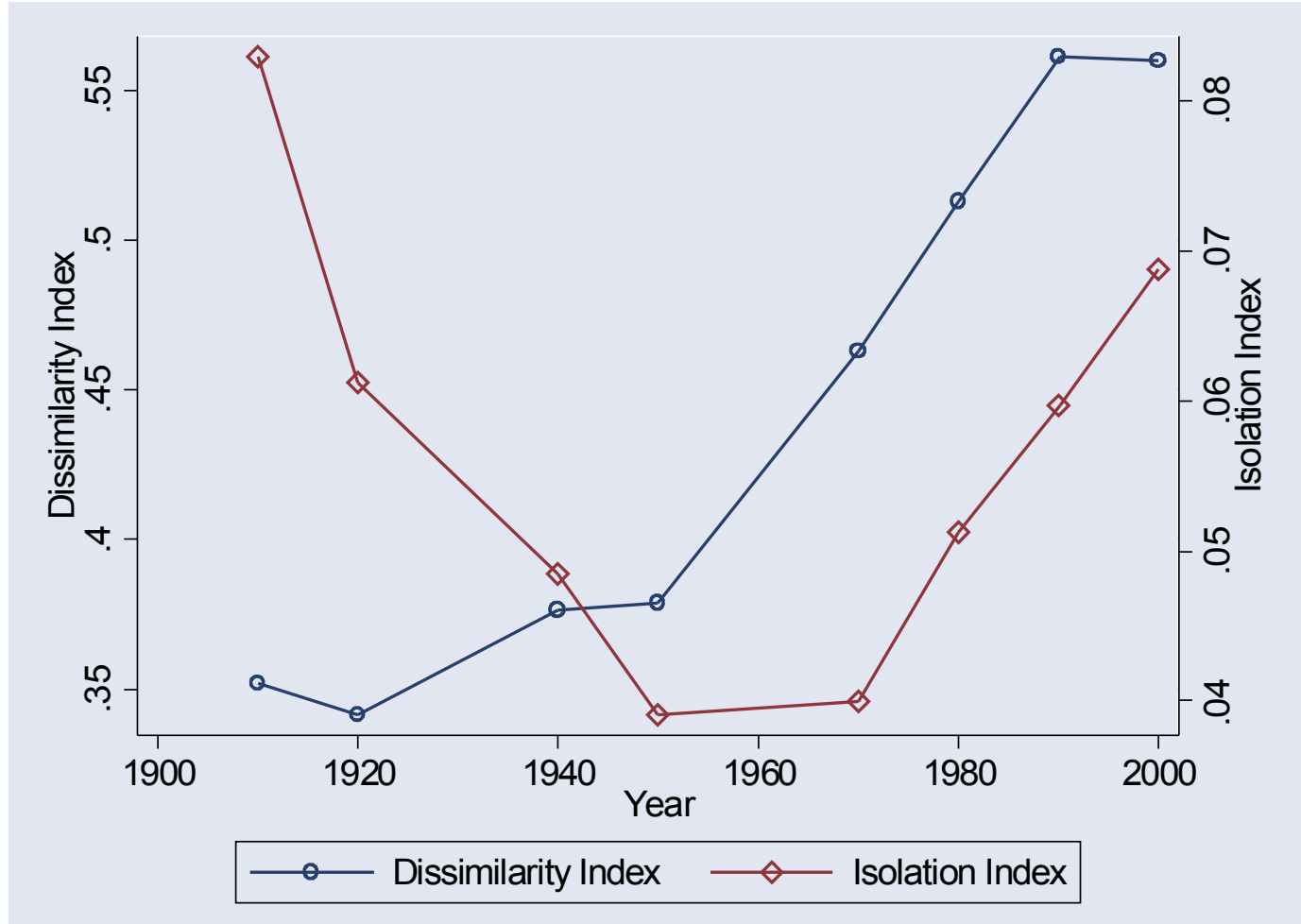

Figure 1: Dissimilarity and Isolation, 1910-2000. Observations are weighted averages of statistics for immigrant communities, with weights equal to the number of immigrants in the community. 
Appendix Table A1: Representative first-stage regression equations

\begin{tabular}{lccc}
\hline & Dissimilarity Index & Isolation Index & Tract Share \\
\hline $\begin{array}{l}\text { Mean years since immigration for } \\
\text { same MSA/country of origin cell }\end{array}$ & 0.003 & $4 * 10^{-4}$ & --- \\
Predicted share based on & $\left(1 * 10^{-4}\right)$ & $\left(2^{*} 10^{-5}\right)$ & 38.27 \\
occupations & --- & -- & $(0.097)$ \\
Group share of MSA population & -0.524 & 0.648 & 0.807 \\
& $(0.011)$ & $(0.004)$ & $(0.011)$ \\
Mean age in MSA/country of & -0.026 & 0.001 & $4 * 10^{-4}$ \\
origin cell & $(0.001)$ & $\left(1 * 10^{-4}\right)$ & $\left(2^{*} 10^{-4}\right)$ \\
Mean education in MSA/country & 0.003 & -0.025 & 0.003 \\
of origin cell & $\left(1 * 10^{-4}\right)$ & $\left(3^{*} 10^{-4}\right)$ & $(0.001)$ \\
& & & \\
Individual level covariates & Yes & Yes & Yes \\
MSA fixed effects & Yes & Yes & Yes \\
Group fixed effects & Yes & Yes & Yes \\
$\mathrm{N}$ & 30,584 & 30,584 & 552,513 \\
$\mathrm{R}^{2}$ & 0.920 & 0.984 & 0.412 \\
\hline
\end{tabular}

Note: These first-stage regressions correspond to two-stage specifications where the dependent variable is a binary indicator for whether the respondent is idle. Standard errors, corrected for within-MSA/group or within-tract/group clustering, in parentheses. 